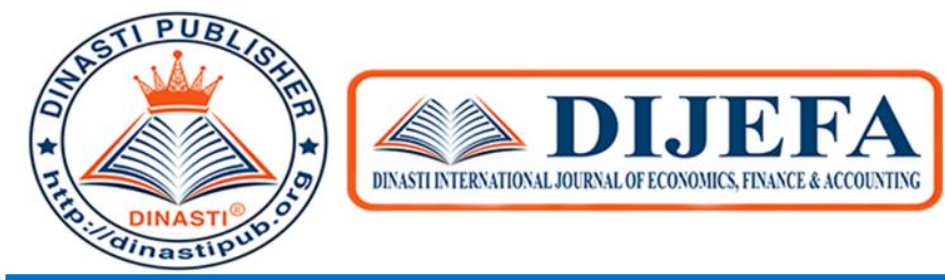

+6281387654578 (9)

+6281387654578 (Q)

https://dinastipub.org/DIJEFA (2)

dinasti-info@gmail.com (๑)

\title{
ENTERPRISE RISK MANAGEMENT DISCLOSURE AS AN INTERVENING \\ VARIABLE IN THE EFFECT OF GOOD CORPORATE GOVERNANCE IMPLEMENTATION AND FIRM SIZE ON FINANCIAL PERFORMANCE (STUDY ON BANKING COMPANIES LISTED ON THE INDONESIA STOCK EXCHANGE FOR THE PERIOD 2013 - 2018)
}

\author{
Dessie Leventa Moezaque ${ }^{1}$, Apollo Daito ${ }^{2}$ \\ ${ }^{1)}$ Universitas Mercu Buana, Jakarta, Indonesia \\ ${ }^{2)}$ Universitas Mercu Buana, Jakarta, Indonesia
}

\begin{tabular}{|c|c|}
\hline $\begin{array}{c}\text { ARTICLE INFORMATION } \\
\text { Received: } 29 \text { March } 2020 \\
\text { Revised: } 20 \text { October } 2020 \\
\text { Issued: } 28 \text { November } 2020 \\
\text { Corresponding author: } \\
\text { E-mail: } \\
\text { 55516120039@ student.mercubuana.ac.id } \\
\text { apollo@mercubuana.ac.id }\end{array}$ & $\begin{array}{l}\text { Abstract: This study aims to examine the effect } \\
\text { of the Implementation of Good Corporate } \\
\text { Governance and Firm Size on Financial } \\
\text { Performance with Enterprise Risk Management } \\
\text { Disclosure as an intervening variable. The } \\
\text { analysis technique used in this study is multiple } \\
\text { linear regression analysis, with the population of } \\
\text { banking companies listed on the Indonesia Stock } \\
\text { Exchange during the period } 2013 \text { to } 2018 \text {. From } \\
\text { the specified sample criteria there were } 39 \\
\text { companies that met the criteria. The results of } \\
\text { this study indicate that (1) GCG implementation } \\
\text { has no significant effect on ERM Disclosure; (2) } \\
\text { Firm Size has a positive and significant effect on } \\
\text { ERM Disclosure: (3) The application of GCG } \\
\text { has a positive and significant effect on Financial } \\
\text { Performance; (4) Firm Size has a positive and } \\
\text { significant effect on Financial Performance; (5) } \\
\text { ERM disclosure has no significant effect on } \\
\text { Financial Performance; (6) ERM disclosure does } \\
\text { not mediate between the Implementation of } \\
\text { GCG to Financial Performance; (7) The } \\
\text { disclosure of ERM does not mediate between } \\
\text { Firm Size and Financial Performance. } \\
\text { Keywords: Good Corporate Governance, Firm } \\
\text { Size, Financial Performance, Enterprise Risk } \\
\text { Management }\end{array}$ \\
\hline
\end{tabular}

\section{INTRODUCTION}

Generally, stakeholders assess a company's excellence through the financial performance. Financial performance measurements will determine the liquidity, solvency, 
profitability and stability (Munawir, 2012: 31). An issue regarding the financial performance occurred in Indonesia banks, there are 26 of 43 banks showed the profit decrease in the first quarter of 2019 compared by the first quarter of 2018 .

Earnings orientation make the companies to encourage the strategies that will be taken to obtain the high profits for the sustainability of the company. Companies are required to be able to anticipate risk, has an information and use appropriate methods in analyzing the company's financial condition. Risk management is a way to identify and manage risks that can affect the achievement of company performance. In addition, good corporate governance can demonstrate management's ability to manage the company. Another factor identified that can affect financial performance is firm size or company size. The size of the company can be interpreted as the size of the company seen from the equity value, the company value, or the total value of the assets of a company.

The purpose of this study is to examine (1) Does the Implementation of GCG affect the ERM Disclosure ?; (2) Does Firm Size affect ERM Disclosure ?; (3) Does the Implementation of GCG affect the Financial Performance ?; (4) Does Firm Size affect Financial Performance ?; (5) Does ERM Disclosure affect Financial Performance ?; (6) Does ERM Disclosure mediate the relationship between GCG Implementation and Financial Performance ?; (7) Does ERM Disclosure mediate the relationship between Firm Size and Financial Performance?

\section{LITERATURE REVIEW}

\section{Agency Theory}

Agency theory indicate that managers will look for opportunities to improve the individual welfare above the company welfare. Agency theory is causes by the information asymmetry between management as principal and stakeholders as agents.

\section{Stakeholder Theory}

Stakeholder theory is a theory that emphasizes that a company is not an entity that operates for personal interests, it must provide benefits to its stakeholders.

\section{Signaling Theory}

Signaling Theory states that by providing relevant pieces of information, recipients of information can influence their behavior to that information. This is related to information about the company for the stakeholders.

\section{Good Corporate Governance}

Corporate governance is a system used in directing and controlling company business activities (Masyhud Ali, 2006). The basic principles of GCG include transparency, accountability, responsibility, independence and fairness.

\section{Firm Size}

Firm Size or company size can be assessed from the amount of equity value, sales value or asset value (Bambang, 2008). In Law of Republic Indonesia No. 10 of 1998 regarding The Banking, types of banks consisting of Commercial Banks and Rural Banks.

\section{Enterprise Risk Management}

Enterprise Risk Management (ERM) is a process that involves the whole entity starting from the board of directors, management and other officials, which is applied in the 
formulation of strategy and covers the entire company, which is designed to identify potential events that could result in the entity, and manage risk in the desired level of risk to provide reasonable guarantees in order to achieve the objectives of the entity. (Robertus, 2016)

\section{Financial Performance}

Financial performance is an illustration of the achievement of a company obtained from the company's financial statements (Rudianto, 2013). The purpose of measuring the company's financial performance is to determine the liquidity, solvency, profitability and stability (Munawir, 2012)

\section{Previous Research}

Several studies related to Good Corporate Governance, Firm Size, Enterprise Risk Management and Financial Performance conducted by upstream researchers include Robert (2008), Lawrence (2009), Christoper (2014) who stated that company size influences ERM. Don Pagach (2010), Cheplel (2013) Kristijadi (2014) which states that ERM influences company performance. Meizaroh (2011), Nurul (2015) which states that GCG has no effect on ERM. Kwanbo (2012), Priyanka (2013), Tamer (2015), Wawan (2015), Aminah (2016) and Djamaluddin (2018) who stated that GCG had no effect on financial performance. Kioko (2013) which states that company size influences financial performance.

\section{RESEARCH METHODS}

The analysis technique used in this study is multiple linear regression analysis, with the population of banking companies listed on the Indonesia Stock Exchange during the period 2013 to 2018. From the specified sample criteria there were 39 companies that met the criteria.

\section{FINDINGS AND DISCUSSION}

\section{A. Data Analysis}

The determination coefficient $\left(\mathrm{R}^{2}\right)$ basically measures how the model's explain the variation of the dependent variable.

Table 1 The Result of Determination Coefficient $\left(\mathrm{R}^{2}\right)$

\begin{tabular}{|l|r|r|r|r|}
\hline \multicolumn{7}{|c}{ Model Summary } \\
\hline Model & \multicolumn{1}{c|}{ R } & R Square & $\begin{array}{c}\text { Adjusted R } \\
\text { Square }\end{array}$ & $\begin{array}{c}\text { Std. Error of } \\
\text { the Estimate }\end{array}$ \\
\hline 1 & $.328^{\mathrm{a}}$ & .328 & .096 & 18.37534 \\
\hline
\end{tabular}

a. Predictors: (Constant), Enterprise Risk Management, Good Corp. Governance, Firm Size

b. Dependent Variable: Financial Performance

(Source: Data processed 2020)

Based on the table above it is known that the determination coefficient $\left(R^{2}\right)$ is 0.328 , it means $32 \%$ contribution of financial performance explained by the three independent variables, namely the implementation of GCG, firm size and ERM disclosure. The remaining $61 \%$ is explained by other variables that has not examined in this study. 
In this study, multiple linear regression analysis is performed on the following equation:

$$
\begin{aligned}
& Y_{1}=\alpha+\beta_{1} X_{1}+\beta_{2} X_{2}+e \ldots \ldots \ldots \\
& Y_{2}=\alpha+\beta_{1} X_{1}+\beta_{2} X_{2}+\beta_{3} Y_{1}+e
\end{aligned}
$$

Where:

$\mathrm{Y}_{1} \quad=$ ERM disclosure

$\mathrm{Y}_{2} \quad=$ financial performance

$\alpha \quad=$ constant

$\mathrm{X}_{1} \quad=$ implementation of GCG

$\mathrm{X}_{2} \quad=$ firm size

$\beta_{1}, \beta_{2}, \beta_{3}=$ regression coefficient

e $\quad=$ error

Table 2 The Result of Multiple Linear Regression Analysis (Model 1)

\section{Coefficients $^{\mathrm{a}}$}

\begin{tabular}{|c|r|r|r|r|r|}
\hline \multirow{2}{*}{ Model } & \multicolumn{2}{|c|}{$\begin{array}{c}\text { Unstandardized } \\
\text { Coefficients }\end{array}$} & $\begin{array}{l}\text { Standardized } \\
\text { Coefficients }\end{array}$ & \multirow{2}{*}{$\mathrm{t}$} & \multirow{2}{*}{ Sig. } \\
\cline { 2 - 5 } & \multicolumn{1}{|c|}{ B } & Std. Error & \multicolumn{1}{c|}{ Beta } & & \\
\hline $1 \quad$ (Constant) & .506 & .110 & & 4.587 & .000 \\
& .141 & .096 & .093 & 1.467 & .144 \\
$\begin{array}{l}\text { Good Corp. } \\
\text { Governance }\end{array}$ & .015 & .004 & .229 & 3.599 & .000 \\
\hline
\end{tabular}

a. Dependent Variable: Enterprise Risk Management

(Source: Data processed 2020)

Table 3 The Result of Multiple Linear Regression Analysis (Model 2)

\section{Coefficients $^{\mathrm{a}}$}

\begin{tabular}{|c|l|r|r|r|r|r|}
\hline \multicolumn{2}{|c|}{ Model } & \multicolumn{2}{|c|}{$\begin{array}{c}\text { Unstandardized } \\
\text { Coefficients }\end{array}$} & $\begin{array}{l}\text { Standardized } \\
\text { Coefficients }\end{array}$ & \multirow{2}{*}{$\mathrm{t}$} & \multirow{2}{*}{ Sig. } \\
\cline { 3 - 5 } \multicolumn{2}{|c|}{} & \multicolumn{1}{c|}{ B } & Std. Error & \multicolumn{1}{c|}{ Beta } & & \\
\hline 1 & (Constant) & -86.833 & 20.882 & & -4.158 & .000 \\
& Good Corp. & 45.297 & 17.505 & .162 & 2.588 & .010 \\
& Governance & 3.561 & .768 & .297 & 4.638 & .000 \\
& Firm Size & -10.817 & 11.916 & -.058 & -.908 & .365 \\
& Enterprise Risk & & & & \\
& Management & & &
\end{tabular}

a. Dependent Variable: Financial Performance

(Source: Data processed 2020)

The path analysis method is used to test the effect of intervening variables. Path analysis is an extension of multiple linear regression analysis, or path analysis is the use of regression analysis to estimate causal relationships between variables that have been 
predetermined based on theory. To determine the effect of this mediation, it was tested using sobel tests.

Table 4 Sobel Test: Mediation Effect of ERM Disclosure in GCG Implementation on Financial Performance

\begin{tabular}{|r|r|r|r|r|r|}
\hline & Input : & & Test statistic : & Std. Error : & p-value : \\
\hline$a$ & 0.141 & Sobel test : & 1.37004206 & 4.66181089 & 0.17067377 \\
\hline$b$ & 45.297 & Aroian test : & 1.33056847 & 4.8001115 & 0.18333104 \\
\hline$S a$ & 0.096 & Goddman test : & 1.41325102 & 4.51927995 & 0.15758913 \\
\hline$S b$ & 11.916 & & & & \\
\hline
\end{tabular}

(Source: Data processed 2020)

Table 5 Sobel Test: Mediation Effect of ERM Disclosure Firm Size on Financial Performance

\begin{tabular}{|c|c|c|c|c|c|}
\hline & Input : & & Test statistic: & Std. Error: & p-value : \\
\hline$a$ & 0.015 & Sobel test: & 2.66962351 & 0.25451342 & 0.00759363 \\
\hline$b$ & 45.297 & Aroian test : & 2.62400558 & 0.25893809 & 0.00869024 \\
\hline$S a$ & 0.004 & Goddman test : & 2.71770647 & 0.25001044 & 0.00657361 \\
\hline$S b$ & 11.916 & & & & \\
\hline
\end{tabular}

(Source: Data processed 2020)

\section{B. Discussion}

The results of the data processing as follow:

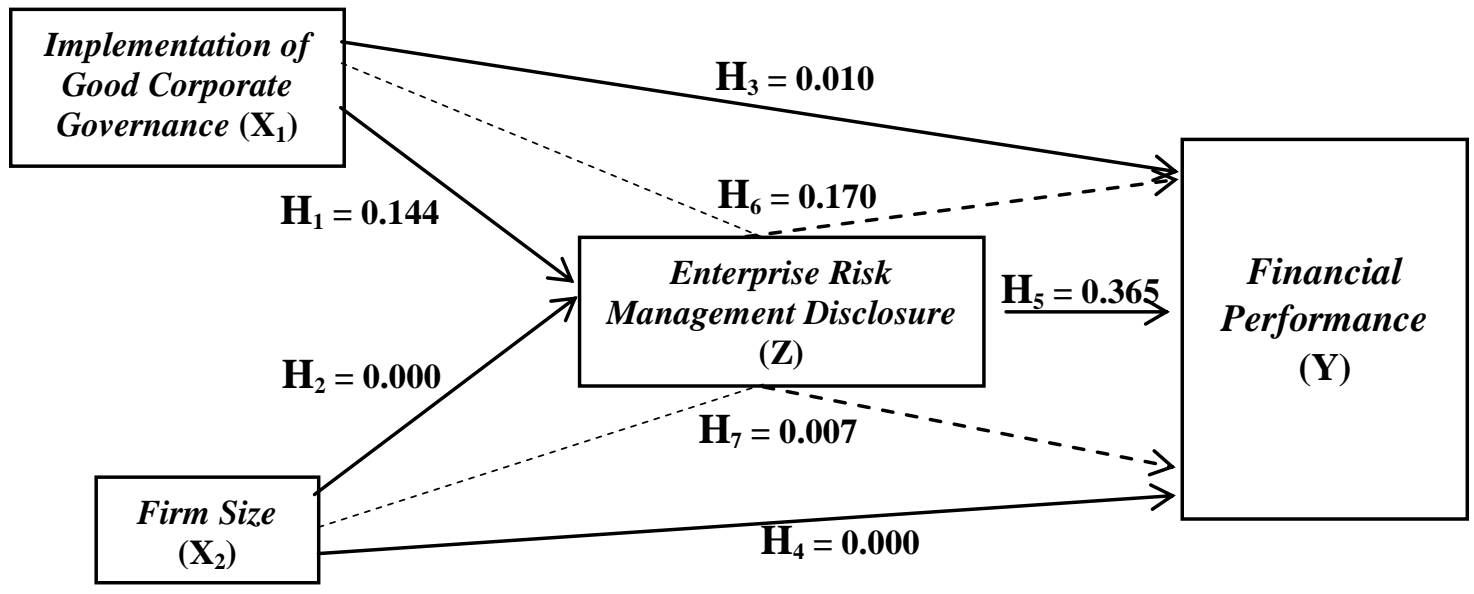

1. Effect of GCG Implementation on ERM Disclosure

Based on the results of testing the first hypothesis which shows that the application of GCG has a significant value of 0.144 greater than 0.05 . It can be concluded that the GCG Implementation variable $\left(\mathrm{X}_{1}\right)$ has no significant effect on ERM Disclosure. The results of this study are not consistent with some previous studies which stated that 
there was a significant influence between auditor reputation and ownership concentration as a proxy of GCG on ERM Disclosures. Inconsistent results are caused because companies need to align corporate governance with risk management. Where the directors, senior management, risk owners, internal auditors, and external auditors must realize that ERM and GCG must develop continuously. ERM and GCG are responsibilities that must be communicated to avoid overlapping between one process and another.

2. Effect of Firm Size on ERM Disclosure

Based on the results of testing the second hypothesis which shows that the Firm Size has a significant value of 0,000 greater than 0.05 . It can be concluded that the Firm Size $\left(\mathrm{X}_{2}\right)$ variable has a positive and significant effect on ERM Disclosure. In accordance with signaling theory, the existence of information about a low company value makes investors assume that the company's risk prospects will threaten the sustainability of the company's performance and encourage investors to divert their investment funds to companies that are more convincing. Information disclosed by companies about managing ERM is captured as negative news by investors when viewed from the management of risks faced both financially and non-financially.

3. Effect of GCG Implementation on Financial Performance

Based on the results of testing the third hypothesis which shows that the application of GCG has a significant value of 0.010 less than 0.05 . It can be concluded that the variable Implementation of GCG $\left(\mathrm{X}_{1}\right)$ has a positive and significant effect on Financial Performance. The Forum of Corporate Governance in Indonesia (FCGI) states that there are several benefits obtained in implementing GCG, including improving company performance through the creation of a better decision making process, improving the efficiency of company operations, and further improving service to stakeholders.

4. Effect of Firm Size on Financial Performance

Based on the results of testing the fourth hypothesis which states that the Firm Size has a significant value of 0,000 smaller than 0.05 . It can be concluded that the Firm Size $\left(\mathrm{X}_{2}\right)$ variable has a positive and significant effect on Financial Performance. This supports the theory that states the size of the company that is proxied by Total Assets shows the size of the company is an important factor in the formation of profits. A big company considered to be more stable and capable of generating profits compared to small companies. The greater the number of assets owned, the more capital received, there will be a lot of money circulation and market capitalization which will further improve the company's financial performance.

5. Effects of ERM Disclosures on Financial Performance

Based on the results of testing the fifth hypothesis which states that ERM Disclosures have a significant value of 0.365 greater than 0.05 . It can be concluded that the ERM Disclosure variable $\left(\mathrm{Y}_{1}\right)$ has no significant effect on Financial Performance. The theory that discloses risk management disclosure is one of the ways companies communicate with stakeholders to show that the company has tried to meet the needs of stakeholders for the information (Kumalasari, 2014). With the risk information, stakeholders can consider the decision to be taken relating to the company. Investors can change their investment decisions, which can decrease the company's financial performance. 
6. Mediation Effect of ERM Disclosure in GCG Implementation on Financial Performance

Based on the results of hypothesis testing through the sobel test which states that the GCG Implementation variable has a p-value of 0.170 above 0.050 . It can be concluded that the ERM Disclosure variable $\left(\mathrm{Y}_{1}\right)$ does not mediate the Implementation of GCG on Financial Performance. The results of this study are in line with research conducted by Nurul (2015) which states the effect of corporate governance and company characteristics on company performance has an indirect effect through the existence of a risk management committee.

7. Mediation Effect of ERM Disclosure Firm Size on Financial Performance

Based on the results of testing the hypothesis through the sobel test which states that the Firm Size has a p-value of 0.007 below 0.050. It can be concluded that the ERM Disclosure variable $\left(\mathrm{Y}_{1}\right)$ mediates between Firm Size and Financial Performance.

\section{CONCLUSION AND SUGESTION}

Based on this research, it concluded that the implementation of GCG has no significant effect on ERM Disclosure, Firm Size has a positive and significant effect on ERM Disclosure, implementation of GCG has a positive and significant effect on Financial Performance, Firm Size has a positive and significant effect on Financial Performance, Disclosure ERM does not have a significant effect on Financial Performance, ERM Disclosures do not mediate GCG Implementation on Financial Performance and ERM Disclosures do not mediate Firm Size on Financial Performance. In connection with the limitations in this study, it is recommended for further researchers can develop other variables such as corporate social responsibility, leverage and growth that can be used as a reference or use other research objects by increasing the number of respondents with the renewal of the research period.

\section{REFERENCE}

Ali, Masyhud. 2006. Manajemen Risiko: Strategi Perbankan dan Dunia Usaha Menghadapi Tantangan Globalisasi Bisnis. PT Rajagrafindo Persada: Jakarta.

Aggarwal, P. 2013. "Impact of Corporate Governance on Corporate Financial Performance”. IOSR Journal of Business and Management, 13(3), 01-05.

Apollo, M. d. 2018. "Influence of Composition Board of Directors, Board of Commissioners, and Audit Committees to Banking Financial Performance (Empirical Study on Banking Industry Listed in BEI 2011-2016)”. International Journal of Innovative Research \& Development, 7(4), 171-176.

Bank Indonesia. (29 April 2013). Pelaksanaan Good Corporate Governance Bagi Bank Umum. Surat Edaran Bank Indonesia Nomor 15/15/DPNP.

Cheplel, S. K. 2013. "The Impact of ERM Practices on The Financial Performance of Commercial Banks in Kenya". University of Nairobi.

Christopher Kibet Yegon, J. G. 2014. "Effects of Firm Size on Enterprise Risk Management of Listed Firms in Kenya". IOSR Journal of Business and Management, 16(5), 86-95.

Daito, Apollo. 2007. Metodologi Penelitian Penyusunan Skripsi. Universitas Budi Luhur: Jakarta. 
Daito, Apollo. 2011. Pencarian Ilmu Melalui Pendekatan: Ontologi, Epistimologi, Aksiologi. Mitra Wacana Media: Jakarta.

Doktoralina, C, Apollo, A. 2019. "The contribution of strategic management accounting in supply chain outcomes and logistic firm profitability”. Uncertain Supply Chain Management, 7(2), 145-156.

Ghozali, Imam. 2015. Aplikasi Analisis Multivariete Dengan Program IBM SPSS 23. Badan Penerbit Universitas Diponegoro: Semarang.

Kioko, N. P. 2013. "The Relationship Between Firm Size and Financial Performance of Commercial Banks in Kenya”. University of Nairobi.

Kristijadi, S. H. 2014. "The Effect of GCG Implementation and Risk Profile on Financial Performance at Go-Public National Commercial Banks". Journal of Indonesian Economy and Business, 29(3), 237-250.

Kwanbo, A. B.-Q. 2012. "Corporate Governance and Financial Performance of Banks in the Post-Consolidation Era in Nigeria”. International Journal of Social Sciences and Humanity Studies, 4.

Lawrence A. Gordon, M. P.-Y. 2009. "Enterprise risk management and firm performance: A contingency perspective”. J. Account. Public Policy 28, 301-327.

Liebenberg, R. E. 2008. "The Value of Enterprise Risk Management: Evidence from the U.S. Insurance Industry”. Terry College of Business University of Georgia.

Lucyanda, M. d. 2011. "Pengaruh Corporate Governance dan Konsentrasi Kepemilikan pada Pengungkapan Enterprise Risk Management”. Simposium Nasional Akuntansi XIV Aceh.

Nurdiawansyah, Aminah. 2016. "The Effect of The Implementation of Good Corporate Governance on The Company Financial Performance”. The Third International Conference on Law, Business and Government.

Nurul Badriyah, R. N. 2015. "The Effect of Corporate Governance and Firm Characteristics on Firm Performance and Risk Management as an Intervening Variable". International Acounting and Business Conference, 868-875.

Riyanto, Bambang. 2008. Dasar-Dasar Pembelanjaan Perusahaan. GPFE: Yogyakarta.

Robertus, Gunawan. 2016. GRC: Konsep dan Penerapannya. PT Rajagrafindo Persada: Depok.

Rudianto. 2013. Akuntansi Manajemen Informasi untuk Pengambilan Keputusan Strategis. Erlangga: Jakarta.

S, Munawir. 2012. Analisis Informasi Keuangan. Liberty: Yogyakarta.

Shahwan, T. M. 2015. "The Effects of Corporate Governance on Financial Performance and Financial Distress: Evidence from Egypt". Corporate Governance: The International Journal of Business in Society, 15.

Undang - Undang No. 10 tahun 1998 tentang Perbankan. (n.d.).

Warr, D. P. 2010. "The Effects of Enterprise Risk Management on Firm Performance". SSRN. 